\title{
Mobile Applications for Agriculture and Allied Sector
}

\author{
R.L. Meena ${ }^{1 *}$, B. Jirli ${ }^{1}$, M. Kanwat ${ }^{2}$ and N.K. Meena ${ }^{3}$ \\ ${ }^{1}$ Department of Extension Education, Institute of Agricultural Sciences, Banaras Hindu \\ University, Varanasi-221005, UP, India \\ ${ }^{2}$ KVK Anjaw, ICAR RC for NEH Region, Basar, Arunachal Pradesh, India \\ ${ }^{3}$ College of Post Graduates Studies, CAU (I), Umiam, Meghalaya, India \\ *Corresponding author
}

\begin{tabular}{l} 
Ke y w or d s \\
$\begin{array}{l}\text { Agriculture, } \\
\text { Farmer, Information } \\
\text { and Knowledge }\end{array}$ \\
\hline Article Info \\
\hline $\begin{array}{l}\text { Accepted: } \\
\text { 20 January } 2018 \\
\text { Available Online: } \\
\text { 10 February } 2018\end{array}$ \\
\hline
\end{tabular}

\section{A B S T R A C T}

Agriculture continues to be the most important sector of the Indian economy and agriculture is a more or less a compulsion for livelihood of million of farmers. Land and water resources have almost reached their limits, price of commodities are fluctuating almost every day, profit are negligible for most of the marginal and small farmers and most of all getting information is cumbersome. In Indian most of the population is dependent on agriculture so there is a need to review and revitalize the mechanism for updating the technology. Majority of the Indian farmers are small-scale producers and are often unable to access the information and technological resources that could increase the yield and lead to better prices for their crops and products. In order to tackle this problem the wide spread network of mobile phones came to the rescue. The mobile phone based solution helps in farm management, leading improvement in agricultural yield and helps in care/maintenance of the farms thus leading agriculture field to its zenith. In present day agriculture, soft resources like knowledge and skill are as important as hard resources like inputs, and sometime more important. But estimate indicate that $60 \%$ of farmers do not access any source of information for advanced agricultural technologies resulting in huge adoption gap. The requirement of field level extension personnel is estimated to be about 1.3-1.5 million against the present availability of about 0.1 million personnel.

\section{Introduction}

Agriculture continues to be the most important sector of the Indian economy. Research, extension and farmers efforts have all contributed significantly in increasing food production from 50 million tonnes in 1950-51 to a land mark achievement of an estimated 259.32 million tonnes in 2011-12 (GoI, 2013). The total demand for food grains is projected to touch 280 million tonnes by the year 2020-
21. Meeting his demand will necessitate a growth rate of nearly two per cent per annum in food grain production (Singh, 2011) and the agriculture sector needs to grow at a targeted four per cent per annum. In Indian most of the population is dependent on agriculture. However, there is also need to review and revitalize the mechanism for updating the technology. In the upcoming years agriculture will see major changes. The vast majority of Indian farmers, which includes small-scale 
producers, are often unable to access the information and technological resources that could increase the yield and lead to better prices for their crops and products. The wide spread network of mobile phones could be the game changer in this problem. It will put agriculture field to its zenith. The main purpose for such project is to develop a mobile phone based solution that helps in farm management, leads to agricultural yield improvement and helps in care/maintenance of the farms (Karkhile, 2015). India's social, economic, cultural situations are so diverse that one need to develop new products and services for these societies.

There are two reasons for the development of knowledge society, - firstly the explosive growth in knowledge, especially in science and technology and secondly people, are moving out of primary occupations such as agriculture and industry to the services sector, where their survival and success depend on their ability to deal with information and knowledge. There are 38 crore mobile telephones in rural areas, 9 crore farm households. Rural India leads a record 35\% surge in use of e-governance. Of the 3.5 billion electronic transactions in $2014,50 \%$ of them were from rural areas, which were responsible for only $20 \%$ of e-transactions in 2013 (Patil, 2015).

This increasing penetration of mobile networks in India therefore presents an opportunity to make useful information more widely available. High resolution cameras, high definition video with huge amount of memory; internet browsing through handset and $3 \mathrm{G}, 4 \mathrm{G}$ and Wireless LAN connectivity are common to find on smart phones these days. As of June'2014 there were 57,380,000 + Google Android and 4,854,000 + Apple ios users in India (Webenza Survey, 2014). The Ministry of Agriculture, Govt. of India, started various schemes in the interests of the farmers for mobile phones. The emergence of new wireless and satellite-based solutions is positioning the developing countries to take the advantage of the benefits to be derived from ICT applications. Mobile or smart phones are becoming an essential device for all types of users irrespective of the age group.

\section{Agricultural applications}

\section{Kisan Suvidha}

Kisan Suvidha is an omnibus mobile app developed to help farmers by providing relevant information to them quickly. With click of a button, they can get the information on weather of current day and next 5 days, dealers, market prices, agro advisories, plant protection, IPM Practices etc. (Table 1).

Unique features like extreme weather alerts and market prices of commodity in nearest area and the maximum price in state as well as India have been added to empower farmers in the best possible manner. https://apps.mgov.gov.in/

descp.do?appid=1056

\section{Pusa Krishi}

ZTM \& BPD Unit; ICAR-IARI, New Delhi is leading 14 ICAR institutes of North Zone-I. The unit strives to be a strong link between the research community and the outside world. It promotes Agribusiness Ventures through technology development and commercialization for everyone from a corporate to an individual farmer.

It has a variety of technologies / products for commercialization. Some technologies may be market ready, however some may require validation and some may require up scaling. It license technologies to both private and public sectors. https://apps.mgov.gov.in/descp.do? appid $=1057$. 


\section{Mkisan application}

This app has been designed and developed by in house IT team of DAC with the help of CDAC Pune. It enables farmers and all other stakeholders to obtain advisories and information being sent by experts and government officials at different levels through mkisan portal without registering on the portal. http://mkisan.gov.in/testimonials. aspx

\section{Shetkari Masik android app}

"Shetkari Masik" is one of the most popular monthly magazines in the Agriculture sector, under publication since 1965. It is published by Deptt. of Agriculture, Maharashtra. The Android app for Shetkari magazine has a very simple interface and requires mobile internet or Wi-Fi connectivity to register and download the issues. Once downloaded, the magazine can be read without internet connectivity. http://www.realit.co.in/

\section{Farm-O-Pedia}

Farm-O-Pedia was developed by C-DAC Mumbai. The application is a multilingual Android application targeted for rural Gujarat. The app is useful for farmers or anyone related to agriculture. It is available in English and Gujarati languages. The main functionalities of the app are: Get suitable crops as per soil and season, Get crop wise information, Check weather in your area and manage your cattle. https://apps.mgov.gov.in/descp.do?appid=587

\section{Bhuvan Hailstorm app}

A mobile app has been developed to capture crop loss happened due to hailstorm. Agriculture Officer will go to the field with mobile or tablet loaded with this mobile app. This mobile app is able to capture following parameters: Photograph of field with latitude and longitude, Name of Crop, Date of sowing, Date of likely harvesting and Source of irrigation. This captured data will automatically be plotted to Bhuvan Portal and analysis can be done easily. https://apps.mgov.gov.in/descp.do?appid=102 9

\section{Crop insurance mobile app}

Crop Insurance mobile app can be used to calculate the Insurance Premium for notified crops based on area, coverage amount and loan amount in case of loanee farmer.

It can also be used to get details of normal sum insured, extended sum insured, premium details and subsidy information of any notified crop in any notified area. https://apps.mgov. gov.in/descp.do?appid=988

\section{Agri-market}

Agri-Market mobile app can be used to get the market price of crops in the markets within 50 $\mathrm{km}$ of the device's location. This app automatically captures the location of person using mobile GPS and fetches the market price of crops in those markets which falls within the range of $50 \mathrm{~km}$.

There is another option to get price of any market and any crop in case person does not want to use GPS location. https://apps.mgov.gov.in/descp.do?appid=989

\section{Kisan Yojana}

This app is an only and exclusive of its kind dedicated to farmers. Information and Knowledge Gap between the rural people is the key challenge for India. Access and Information about government's schemes for farmers is not as easy compare to other countries. This App provides useful information about Government's Schemes to 
farmers from their respective State Agriculture department. https://play.google.com/store/ apps/detailsid=com.purplechai.admin.kissanyo jnaappandhl=en.

\section{Kheti Badi}

This app is for agriculture traders and farmers in India. They are now able to get the prices online. App is covering most of the farm product from all over the Indian agriculture markets, market yard and mandi. For now app is listing previous day closing prices.

This App can help farmers to convert their chemical farming to Organic Farming, make informed decisions to improve their livelihoods and connect them to consumers to gain bigger pie of the supply chain. https://play.google.com/store/apps/details?id=t etarwalsuren.khetibarikijankariandhl=en.

\section{Modern Kheti}

Modern kheti, as the name indicates, relates to the modern agricultural techniques; conservative and cash crops, allied professions and farm machinery through training programs or upcoming events on a national and international level. Introduced in 1987, it is the leading and most widely read agriculture based magazine throughout Northern India. The main aim of Modern Kheti is to keep up the spirit of farming, bond different regions and help agriculture grow. https://play.google.com/store/apps/details?id= com.magzter.modernkhetihindiandhl=en

\section{Organic farming}

This app provides wide range of intrinsic information on organic farming with added visuals in the "Organic Farming" app to enhance your learning. https://play.google. $\mathrm{com} /$ store/apps/details?id=com.xenon.organicf armingandhl=en.

\section{IFFCO Kisan}

"IFFCO Kisan" is an Indian agriculture farmer suvidha App, which helps the Indian farmer/ Kisan to take informed decisions by accessing customized agricultural information related to their need. Agriculture suvidha app is for Kisan suvidha and provides the latest mandi prices, weather forecast, agricultural advisory, best practices tips related to agriculture, Animal Husbandry, horticulture; a buyer and seller platform, and all agriculture related news and govt. schemes. This Indian farmer app is for Kisan suvidha to provide agriculture alerts and agriculture advisories in 11 Indian languages in text as well as agriculture audio clip for the convenience of the farmers who are most comfortable in their own language. https://play.google.com/store/apps/details?id= com.IFFCOKisanandhl=en

\section{Kisaan market}

Kisaan Market empowers Indian Farmers to connect directly with buyers and saves brokerages and transport spendings. Which ultimately multiplies their benefits and insights, latest updates on Mandi prices, Krushi Tips, weather and news as per their location in preferred language. Features: Latest Mandi Prices (market yard rates), Weather forecast for user's location, Krushi Tips, Government Schemes and Subsidies for Kisan (Farmer), Sale product, Buy Product, Supported Languages: English, Hindi, Marathi. All the information is personalized, and farmers can update markets location and language. Farmer can Sale and Buy their products through Kisan Market mobile App. Farmer (any user of Kisan market) can easily upload their product details on App which is available to all other user. Buyer can filter search product by category and commodity wise. https://play.google.com/store/apps/ details?id=com.rikwaa.kisanmarket 


\section{Bazar Ke Bhav}

Bazar ke Bhav covers Fastest Media Group for Malawa Region Mandi News. We are also Report and Rate Update of Overall India's Mandi.

https://play.google.com/store/apps/details?id= com.wBazarkeBhav

\section{Mandi prices}

Information Systems is the backbone for marketing any Product. Indian Farmers can now get whole sale prices of Farm produce across various Mandi's on their Smart Phones. Farmers can also send details about their farm produce on the Smart Phone. The Price Information is refreshed repeatedly every day. The Data is loaded from Government Servers located at http://data.gov.in. https://play.google.com/store/apps/details?id= com.appface.mandiprices

\section{RML farmer - Krishi Mitr}

RML Farmer is one of its kind agricultural app where farmers can keep up with latest commodity and mandi prices, farm and farmer related news, weather forecast and advisory, provides agricultural advice all news regarding government's agricultural policies and govt. schemes.

This kisan suvidha app (suvidha is a hindi word which means comfort / convenience / ease) empowers those involved in agriculture and allied occupations in taking informed decisions by providing easy access to personalized and unbiased agriculture insights as per their location and in their preferred language. Users can choose from over 450 crop varieties, 1300 mandis, and 3500 weather locations across 50,000 villages and 17 states of India. https://play.google.com/store/ apps/details?id=com.rml.Activities.

\section{Agriscience Krushi Mahiti}

Agriscience Krushi Mahiti is a Gujarati mobile application for farmers. This app provides latest updates of market rates of almost all APMC (Mandis) of Gujarat. Our app also updates the farmers about latest agriculture news of all over the globe. We provide unbiased agriculture content and actionable information at every stage of crop cycle. https://play.google.com/store/apps/ details?id=com.agriscienceapp.

\section{Vivasayam in Tamil}

Vivasayam in Tamil. You can see here all type of Agriculture news in Tamil. https://play. google.com/store/apps/details?id=com.Aapp.v ivasayamintamil

\section{Agri-Sakthi}

Agri-Sakthi Hyper Local Market for Farmers who is doing farming they will sell here, its multi-vendor Application so you can sell your products and monitor your sale on your Dash Board.

https://play.google.com/store/apps/details?id= com.Aapp.agrisakthi

\section{Agri-app}

It provides complete information on Crop Production, Crop Protection and all relevant agriculture allied services on your Smartphone. In addition to being an information portal, Agri-App is also an online market place bringing farmers, agri. inputs, and retail and fulfillment services on a common digital platform. AgriApp is now available in Kannada, English, Hindi, Telugu, Tamil and Marathi. This app enables farmers to access to all the information related to "High value, low product "category crops from Varieties, soil/ climate to harvesting and storage procedure. 
Table.1 Mobile application and their users

\begin{tabular}{|l|lc}
\multicolumn{1}{|c|}{ Applications } & User's & Source (Ref.) \\
\hline Kisan Suvidha & 297980 & {$[7]$} \\
\hline Pusa Krishi & 42584 & {$[8]$} \\
\hline & & \\
\hline & & {$[13]$} \\
\hline Farm-O-Pedia & 5143 & {$[6]$} \\
\hline Bhuvan Hailstorm App & 447 & {$[15]$} \\
\hline Crop Insurance Mobile App & 19028 & {$[16]$} \\
\hline Agrimarket & 25249 & {$[27]$} \\
\hline Kisan Yojana & $100000-500000$ & {$[36]$} \\
\hline Kheti Badi & $100000-500000$ & {$[26]$} \\
\hline Modern Kheti & $50000-100000$ & {$[32]$} \\
\hline Organic Farming & $10000-50000$ & {$[25]$} \\
\hline Iffco Kisan & $100000-500000$ & {$[28]$} \\
\hline Kisaan Market & $10000-50000$ & {$[31]$} \\
\hline Bazar Ke Bhav & $50000-100000$ & {$[22]$} \\
\hline Mandi Prices & $10000-50000$ & {$[29]$} \\
\hline Rml Farmer - Krishi Mitr & $100000-500000$ & {$[21]$} \\
\hline Agriscience Krushi Mahiti & $10000-50000$ & {$[19]$} \\
\hline Vivasayam In Tamil & $100000-500000$ & {$[18]$} \\
\hline Agrisakthi & $100-500$ & {$[24]$} \\
\hline Agriapp & $100000-500000$ & {$[35]$} \\
\hline Krishi Gyan - Telugu & $1000-5000$ & {$[10]$} \\
\hline Sikkim Horticulture and Cash crop Assistance & 551 & {$[11]$} \\
\hline Sikkim Allotment Of Breeding Bull & 529 & {$[12]$} \\
\hline Application For Poultry & 2370 & {$[33]$} \\
\hline Pashu Poshan & 50000 & {$[23]$} \\
\hline Digital Mandi India & 50000 & {$[20]$} \\
\hline Agricultural Business & $50000-100000$ & \\
\hline Agri Live & $5000-10000$ & \\
\hline & 50000 & {$[17]$} \\
\hline Karnataka Bhoomi & 129 & $31]$ \\
\hline Hp Soil Testing & 50000 & \\
\hline Intelligent Advisory System For Farmers & & \\
\hline Crop Info & & \\
\hline
\end{tabular}


Farmers can directly chat with our scientists through this feature. https://play.google.com/ store/apps/details?id=com.criyagenandhl=en

\section{Krishi Gyan - Telugu}

Krishi Gyan is an application aimed at disseminating agricultural information to rural, farming audiences. This application will enable Indian farmers to connect with Krishi Gyan experts and ask their questions related to farming and get the answers within the application through notification. The farmers as well as agriculture enthusiast can also share their answer with each other. https://play.google.com/store/apps/details?id= org.isapindia.www.krishigyan_telugu

\section{Horticulture and animal husbandry}

\section{Sikkim horticulture and cashcrop assistance}

This app is used for submitting online application for obtaining Departmental assistance by farmers of Sikkim. https://apps.mgov.gov.in/descp.do?appid=331 andparam $=\mathrm{app}$

\section{Sikkim allotment of breeding bull}

This app is used for making request for allotment of breeding bull under Animal Husbandry department of government of Sikkim. https://apps.mgov.gov.in/descp.do? appid=333andparam=app

\section{Application for poultry}

It is developed by C-DAC Mumbai. The Animal Husbandry Department of Himachal Pradesh has introduced Backyard Poultry Scheme under the Centrally Sponsored Scheme, where low input technology birds of colored strain but disease resistant type are supplied to the farmers of the state. With the help of this app, an applicant who wants to obtain assistance under Poultry Chick and Backyard Poultry Schemes of Govt. of Himachal Pradesh can apply online. https://apps.mgov.gov.in/descp.do?appid=388

\section{Pashu Poshan}

NDDB has developed android based software that can be used on phones as well as tablets. Milk producers are advised to adjust the quantity of locally available feed ingredients offered to their animals along with mineral mixture. With the help of this software balanced ration is formulated while optimizing the cost considering animal profile, i.e. Age of cattle or buffalo milk production, milk fat and feeding regime etc. https://play.google.com/store/apps/details?id= coop.nddb.pashu_poshanandhl=enandrdid=co op.nddbpashu_poshan

\section{Digital Mandi India}

This App helps in checking the latest Indian agricultural commodities Mandi prices from different states and districts. Easy to use and intuitive, the app enables farmers, traders and all others to know the updated Mandi price from anywhere. Its main features are: Browse through various commodity categories, Browse prices in different states, Simplified flow to reach the selected commodity's mandi price and Copy the mandi price of a commodity. https://play.google.com/store/ apps/details?id=com. appkiddo.smartfarmeran $\mathrm{dhl}=\mathrm{en}$

\section{Agricultural business}

This app will gives deep and insight information about agriculture while providing opportunities for small, medium and large agric enterprises to have an online presence and marketing platform for their business. https://play.google.com/store/apps/details?id= com.AgriculturalBusiness3dsp 


\section{Agri live}

Free online platform for farmers to showcase their Crops and Agricultural products for sale. Farmers of all Agricultural produces (Grains, Pulses, Vegetables, Fruits, Flowers, Spices, Wood, Livestock, Aqua, Seeds, etc.) can add their crop details online for sale. Farmers, agriculture product Traders, agriculture product Exporters, Agents and everyone are provided with daily mandi price / market price information for transparency in agricultural products price negotiations and sale transactions. Agri Live aims to create a unified transparent agriculture market system by uniform distribution and steady demand of agriculture produces; a response to the Make in India call and supplement effort to E-Nam (electronic National Agriculture Market). Agri Live is available in multiple regional languages such as Bengali, Hindi, Kannada, Malayalam, Marathi, Punjabi, Tamil and Telugu. https://play.google.com/store/apps/ details?id=agri.live

\section{MNCFC}

This Android based application, developed by National Remote Sensing Centre, ISRO, is useful for field data collection for crop assessment using satellite data under FASAL project of Ministry of Agriculture. The application can be used for collecting Field Photographs (640x480 resolution), GPS coordinates and Field information, such as crop type, condition, sowing date, soil type, etc. The farmers can also upload pictures taken through their mobile devices depicting status of the crops, varieties and soil as crowd sourcing. This information will be extremely useful in creating a national geospatial database of crops. The information can be sent in real-time, or later on using the Send Later option. All data received through this application reaches at ISRO's Bhuvan Server.

\section{Karnataka Bhoomi}

Bhoomi (meaning land) is the project of online delivery and management of land records in Karnataka. Framers of Karnataka know the status of their application through this app. https://play.google.com/store/apps/details?id= dev.dragon.karnatakaBhoomiandhl=en

\section{HP soil testing}

This app has been developed by C-DAC Mumbai for agriculture department of Himachal Pradesh. With the help of this app farmers can submit soil health samples of their land to the concerned soil health testing lab of their district / Block. https://apps.mgov. gov.in/descp.do?appid=250

\section{Intelligent advisory system for farmers}

It was developed by CDAC Mumbai. Farmers can get different farming season details; month based atmospheric and ideal conditions for variety of crops. https://apps.mgov.gov.in/ descp.do?appid=662

\section{Crop Info}

Developed by Nirantara Livelihood Resources Private Limited, Bangalore, Karnataka. The Crop Info App provides Production Technology of commercially important Horticultural and Agricultural crops on your smart phone. It provides production aspects, post-harvest technology, processing possibilities and market information. Crop Info is an App specifically developed for students and faculty of Agricultural and Horticultural Universities, Subject Matter Specialists and Extension Officials of Agriculture and Horticultural Departments, Private Sector Professionals, Farmers and anyone interested in cultivation of crops. https://play.google.com/store/apps/details?id= 
com. saaranga.cropinfoandhl=enandrdid=com . saaranga.cropinfo

Precision farming is encouraged through soil sampling, data collection, and data analysis; enable localized variation of chemical applications and planting density to suit specific areas of the field. These applications help to increases the productivity. There is an elimination of the need for human "flaggers" increases farmer's efficiency and the return is assured with the help of these applications by facilitating market access.

\section{References}

Agmarket, (2015). Directorate of Marketing and Inspection (DMI), Ministry of Agriculture, Government of India. http://www.agmarket.nic.in 25 January 2015.

GoI. (2013). State of Indian Agriculture 201213. Published by the Ministry of Agriculture, Department of Agriculture and Co-operation, Directorate of Economics and Statistics, New Delhi. agricoop.nic.in/Annual report201213/ARE 2012-13/pdf, OpenWeather Map API. https://openweathermap.org/. http://bhuvan.nrsc.gov.in/governance/moafw_ hailstorm

http://landrecords.karnataka.gov.in/service0/ http://mkisan.gov.in/testimonials.aspx http://www.realit.co.in/ http://www.webenza.com/android-vs-iossmartphone-users-inindia-2014infograph/

https://apps.mgov.gov.in/descp.do?appid=102 9

https://apps.mgov.gov.in/descp.do?appid=105 6

https://apps.mgov.gov.in/descp.do?appid=105 7

https://apps.mgov.gov.in/descp.do?appid=250 https://apps.mgov.gov.in/descp.do?appid=331 andparam $=$ app https://apps.mgov.gov.in/descp.do?appid=333 andparam $=$ app

https://apps.mgov.gov.in/descp.do?appid=388 https://apps.mgov.gov.in/descp.do?appid=587 https://apps.mgov.gov.in/descp.do?appid=662 https://apps.mgov.gov.in/descp.do?appid=988 https://apps.mgov.gov.in/descp.do?appid=989 https://play.google.com/store/apps/details?id= agri.live

https://play.google.com/store/apps/details?id= com.Aapp.agrisakthi

https://play.google.com/store/apps/details?id= com.Aapp.vivasayamintamil

https://play.google.com/store/apps/details?id= com.AgriculturalBusiness3dsp

https://play.google.com/store/apps/details?id= com.agriscienceapp

https://play.google.com/store/apps/details?id= com.appface.mandiprices

https://play.google.com/store/apps/details?id= com.appkiddo.smartfarmerandhl=en

https://play.google.com/store/apps/details?id= com.criyagenandhl=en

https://play.google.com/store/apps/details?id= com.IFFCOKisanandhl=en

https://play.google.com/store/apps/details?id= com.magzter.modernkhetihindiandhl=e $\mathrm{n}$

https://play.google.com/store/apps/details?id= com.purplechai.admin.kissanyojnaappa ndhl=en

https://play.google.com/store/apps/details?id= com.rikwaa.kisanmarket

https://play.google.com/store/apps/details?id= com.rml.Activities

https://play.google.com/store/apps/details?id= com.saaranga.cropinfoandhl=enandrdid =com.saaranga.cropinfo

https://play.google.com/store/apps/details?id= com.wBazarkeBhav

https://play.google.com/store/apps/details?id= com.xenon.organicfarmingandhl=en

https://play.google.com/store/apps/details?id= coop.nddb.pashu_poshanandhl=enandrd $\mathrm{id}=$ coop.nddb.pashu_poshan

https://play.google.com/store/apps/details?id= 
dev.dragon.karnatakaBhoomiandhl=en https://play.google.com/store/apps/details?id= org.isapindia.www.krishigyan_telugu https://play.google.com/store/apps/details?id= tetarwalsuren.khetibarikijankariandhl=e n

Karkhile, S.G. and Ghuge, S.G. (2015). A Modern Farming Techniques using Android Application. International Journal of Innovative Research in
Science, Engineering and Technology, 4(10).

Singh, M. (2011). ICAR-83 ${ }^{\text {rd }}$ Foundation Day Address. ICAR press release, dated $16^{\text {th }}$ July, 2011, www.icar.org.in (Accessed on $7^{\text {th }}$ August, 2011).

Webenza, (2014). Android vs. IOS Smartphone Users in India, 2014 Infograph,

\section{How to cite this article:}

Meena, R.L., B. Jirli, M. Kanwat and Meena, N.K. 2018. Mobile Applications for Agriculture and Allied Sector. Int.J.Curr.Microbiol.App.Sci. 7(02): 2317-2326. doi: https://doi.org/10.20546/ijcmas.2018.702.281 